\title{
Differential Postreceptor Signaling Events Triggered by Excitotoxic Stimulation of Different Ionotropic Glutamate Receptors in Retinal Neurons
}

\author{
Armanda E. Santos, ${ }^{1,2}$ Ana L. Carvalho, ${ }^{1}$ Maria C. Lopes, ${ }^{1,2}$ and Arsélio P. Carvalho ${ }^{1 \star}$ \\ ${ }^{1}$ Center for Neuroscience of Coimbra, Department of Zoology, University of Coimbra, Coimbra, Portugal \\ ${ }^{2}$ Faculty of Pharmacy, University of Coimbra, Coimbra, Portugal
}

The aim of this work was to investigate whether excitotoxicity induced by overstimulation of different ionotropic glutamate receptors could trigger different intracellular signaling cascades. Cultured chick neuronal retina cells, essentially amacrine-like, were particularly sensitive to the toxicity induced by non-NMDA glutamate receptor agonists. One hour stimulation with $100 \mu \mathrm{M}$ kainate induced a reduction of cell viability of about $44 \%$, as assessed by the MTT test $24 \mathrm{hr}$ after stimulation. Kainate-induced toxicity was mediated through AMPA receptors. Glutamate $(100 \mu \mathrm{M}, 1 \mathrm{hr})$ reduced cell viability by $26 \%$, essentially acting through N-methyl-Daspartate receptors. Five hours after stimulation, neuronal retina cells had an apoptotic-like nuclear morphology. In retinal neurons, the excitotoxic stimulation, with either glutamate or kainate, induced a calciumdependent enhancement of the DNA-binding activity of the activating protein-1 (AP-1) transcription factor, which was maximal $2 \mathrm{hr}$ after stimulation. Glutamate induced a greater increase in the AP-1 DNA-binding activity than did kainate. Supershift assays using antibodies directed against different members of the Fos and Jun protein families showed that the AP-1 complex in retinal neurons includes proteins of the Fos family, namely, Fra-2, c-Jun, and Jun D. The DNA-binding activity of the nuclear factor-кB transcription factor was not significantly changed upon excitotoxic stimulation with any agonist. Stimulation of glutamate receptors with $100 \mu \mathrm{M}$ kainate or $100 \mu \mathrm{M}$ glutamate for $2 \mathrm{~min}$ was sufficient to induce the activation of the extracellular signal-regulated kinase (ERK). Inhibition of the ERK activation with the MEK inhibitors U 0126 and PD 98059 increased the toxicity induced by kainate but was without effect on the toxicity induced by glutamate. These results indicate that, although stimulation with both glutamate receptor agonists increased ERK phosphorylation, only kainate-induced ERK activation correlates with the activation of a survival signaling pathway. Our results suggest that, in chick embryo retinal neurons, the signaling pathways that mediate excitotoxic cell death and neuroprotection are stimulus specific. J. Neurosci. Res. 66:643-655, 2001.

(๖) 2001 Wiley-Liss, Inc.
Key words: AMPA receptors; AP-1 transcription factor; extracellular signal regulated-kinase; neuroprotection; apoptosis

Excitotoxic neurodegeneration involves overactivation of ionotropic glutamate receptors (Olney, 1978; Choi, 1988), which consist of the N-methyl-D-aspartate (NMDA) and non-NMDA receptors, including the $\alpha$-amino-3-hydroxy-5-methyl-4-isoxazolepropionic acid (AMPA) and kainic acid (KA) receptors (Hollmann and Heinemann, 1994; Bettler and Mulle, 1995). Excitotoxicity has been implicated in several neuronal disorders, such as cerebral ischemia, epilepsy, and Huntington's, Parkinson's, and Alzheimer's diseases (Bittigau and Ikonomidou, 1997; Martin et al., 1998; Doble, 1999; White et al., 2000). Ischemia or excitotoxic insults to the rabbit or chick retina point to a high sensitivity of retinal amacrine cells to overstimulation of the ionotropic glutamate receptors (Osborne and Herrera, 1994; Zeevalk and Nicklas, 1994; Osborne et al., 1995, 1996; Chen et al., 1999; for review see Duarte et al., 1998).

The overactivation of glutamate receptors can induce apoptotic cell death by a mechanism involving calcium influx (Ankarcrona et al., 1995; Glazner et al., 2000), and such toxicity may occur in acute neurodegenerative conditions, such as ischemia, trauma, and severe epileptic seizures, as well as in Alzheimer's disease and motor system disorders (Choi, 1996; Mattson, 2000). Often, the intensity of the same initial insult decides the prevalence of either apoptosis or necrosis (Bonfoco et al., 1995).

Apoptosis can be attenuated, in some cases, by inhibitors of protein synthesis, suggesting that transcription and translation of new products could be important during

Contract grant sponsor: Portuguese Science and Technology Foundation; Contract grant number: SAU/14120/98.

${ }^{\star}$ Correspondence to: Arsélio Pato de Carvalho, Center for Neuroscience of Coimbra, Department of Zoology, University of Coimbra, 3004-517 Coimbra, Portugal. E-mail: carvalho@cnc.uc.pt

Received 8 May 2001; Revised 13 August 2001; Accepted 21 August 2001 
cell death. The induction of the activator protein-1 (AP-1) transcription factor has been associated with apoptosis in neuronal cells (Kaminska et al., 1994; Finiels et al., 1995; Kasof et al., 1995; Wenzel et al., 2000). AP-1 is a homodimeric and/or heterodimeric protein complex composed of members of the Fos and Jun families (Angel and Karin, 1991; Herdegen and Leah, 1998; Pennypacker, 1998). These proteins are able to modulate transcription of target genes, following formation of the dimeric AP-1 complex, and DNA-binding through their "leucinezipper" motifs. Stimulation of ionotropic glutamate receptors has been shown to induce an increase of the AP-1 DNA-binding activity in a variety of neuronal systems (Condorelli et al., 1994; Kasof et al., 1995; Hou et al., 1997; Schwarzschild et al., 1997; Kitayama et al., 1999; Kovács et al., 1999; Yoneda et al., 1999). Furthermore, activation of glutamate receptors can increase the activity of mitogen-activated protein kinases (MAPKs), in a calcium-dependent manner, through stimulation of the NMDA receptors (Bading and Greenberg, 1991; Kurino et al., 1995; Xia et al., 1996; Schwarzchild et al., 1999; Jiang et al., 2000). MAPKs are a family of serine/threonine kinases that include p44/42 extracellular signal-regulated kinases, ERK 1 and ERK 2, respectively, c-Jun $\mathrm{N}$-terminal protein kinases (JNKs), and p38 MAP kinase, which can contribute to the induction of AP-1 activity in response to a diverse array of extracellular stimuli (Karin, 1995).

Among the ionotropic glutamate receptor agonists, kainate is the most potent excitotoxin both for the intact chick embryo retina (Chen et al., 1999) and for cultured chick amacrine-like neurons (Ferreira et al., 1996, 1998). The kainate-induced toxicity in cultured chick amacrinelike neurons is due to excessive activation of AMPA receptors. Moreover, the blockade of AMPA receptor desensitisation with cyclothiazide potentiates cell damage induced by AMPA (Ferrreira et al., 1998). Several reports from other neuronal systems also show an increase in AMPA receptor-mediated neurotoxicity and $\mathrm{Ca}^{2+}$ influx when the desensitisation of AMPA receptor is blocked with cyclothiazide (Cebers and Liljequist, 1995; Cebers et al., 1997; Ohno et al., 1997, 1998; Ferreira et al., 1998; Jensen et al., 1998; Ambrósio et al., 2000).

In cultured chick amacrine-like cells, small $\mathrm{Ca}^{2+}$ loads through NMDA or AMPA receptor-associated channels have different effects on cell viability (Ferreira et al., 1996). This evidence, together with the fact that cultured amacrine cells are particularly sensitive to excitotoxic activation of AMPA receptors (Ferreira et al., 1998), points to the need for further studies to clarify the different intracellular mechanisms mediated by different ionotropic glutamate receptors upon an excitotoxic stimulus. Furthermore, cultured chick amacrine-like cells, which contain $\mathrm{Ca}^{2+}$-permeable AMPA receptors (Duarte et al., 1996, 1998), are a relevant model for studying toxicity mediated by AMPA receptors. We investigated eventual differences in postreceptor events mediated by different ionotropic glutamate receptors upon excitotoxic stimula- tion of cultured chick amacrine-like neurons and found that overactivation of ionotropic glutamate receptors induces apoptotic-like cell death and activation of the transcription factor AP-1, but not of the nuclear factor $(\mathrm{NF})-\kappa \mathrm{B}$ transcription factor. Moreover, we show that stimulation of either AMPA or possibly NMDA receptors increases ERK activity, but only kainate-induced toxicity is protected by activation of the ERK pathway, suggesting stimulus-specific neuroprotection pathways in retinal neurons.

\section{MATERIALS AND METHODS}

\section{Materials}

Fetal calf serum was purchased from Biochrom KG (Berlin, Germany), trypsin and gentamicin from Gibco BRL Life Technologies (Paisley, United Kingdom). 6-Cyano-7nitroquinoxaline-2,3-dione (CNQX) and cyclothiazide (CTZ) were obtained from Tocris Cookson Ltd. (Bristol, United Kingdom). LY 303070 was a gift from Eli Lilly Co. (Indianapolis, IN). MK-801 was obtained from Merk Sharp \& Dohme Reseach Laboratories (Rahway, NJ). The MAPKs inhibitors PD 98059, U 0126, and SB 203580 were from CalbiochemNovabiochem Corp. (Darmstadt, Germany). The DNA stains propidium iodide and Syto-13 were from Molecular Probes Europe (Leiden, The Netherlands). The oligonucleotides with consensus binding motifs for the AP-1 and NF- $\mathrm{kB}$ transcription factors were from Santa Cruz Biotechnology, Inc. (Heidelberg, Germany). T4 polynucleotide kinase was from USB Corporation (Cleveland, $\mathrm{OH}$ ), and Sephadex G-50 spin column, poly(dIdC), and $\left[\gamma-{ }^{32} \mathrm{P}\right] \mathrm{ATP}, 10 \mathrm{mCi} / \mathrm{ml}$, were purchased from Amersham Pharmacia Biotech (Buckinghamshire, United Kingdom). The rabbit antiactive MAPK antibody was from Promega (Madison, WI). The alkaline phosphatase-conjugated anti-rabbit and anti-mouse $\operatorname{IgG}$ were from Amersham Pharmacia Biotech. The mouse monoclonal anti- $\alpha$-tubulin was obtained from Zymed Laboratories, Inc. (San Francisco, CA). The BCA assay kit was from Pierce (Rockford, IL). The following antibodies, raised against members of the AP-1 transcription factor, were purchased from Santa Cruz Biotechnology, Inc., and were used for supershift analysis: c-Fos (sc-253-G), Fra-2 (sc-604), Fos B (sc-48), Jun B (sc-46-G), c-Jun/AP-1 (sc-45-G), Jun D (sc-74G), and ATF-2 (sc-187). The c-Fos, Fra-2, and c-Jun/AP1 antibodies are chicken reactive according to the manufacturer's specification. All other reagents were from Sigma Chemical Co. (St. Louis, MO) or from Merck (Darmstadt, Germany). Stock solutions of CNQX, LY 303070, PD 98059, U 0126, SB 203580, and Syto-13 were made in dimethyl sulfoxide. All the other chemicals were kept in aqueous stocks.

\section{Culture of Chick Retina Cells}

Primary cultures of chick retinal neurons were prepared from 8-day-old chick (white leghorn) embryos as described previously (Duarte et al., 1992). Retinas were dissected free from other ocular tissues and incubated for $15 \mathrm{~min}$ at $37^{\circ} \mathrm{C}$ in $\mathrm{Ca}^{2+}, \mathrm{Mg}^{2+}$-free Hank's balanced salt solution, supplemented with $0.1 \%$ trypsin. The digested tissue was centrifuged at $140 \mathrm{~g}$ for $1 \mathrm{~min}$, and the pellet was resuspended in Eagle's basal medium (Earl's salts; BME) buffered with $25 \mathrm{mM}$ HEPES and 
$10 \mathrm{mM} \mathrm{NaHCO}$ and supplemented with $5 \%$ heat-inactivated fetal calf serum and gentamicin $(60 \mu \mathrm{g} / \mathrm{ml})$. After mechanical dissociation, cells were seeded at $0.6 \times 10^{6}$ cells $/ \mathrm{cm}^{2}$ in $12-$ well plates for neuronal injury assays or at $0.94 \times 10^{6} \mathrm{cells} / \mathrm{cm}^{2}$ in $100 \mathrm{~mm}$ dishes for the transcription factors or the MAPK activation studies. The retinal neurons were cultured for 5 days in BME supplemented as described above, without medium changes during the culture period. Cells were cultured at $37^{\circ} \mathrm{C}$, in a humidified atmosphere of $95 \%$ air $/ 5 \% \mathrm{CO}_{2}$. It was confirmed by immunocytochemistry, using antibodies against choline acetyltransferase and against $\gamma$-aminobutyric acid (GABA), that our cultures of retinal neurons are highly enriched in amacrine-like neurons (Santos et al., 1998).

\section{Exposure to Excitatory Amino Acids}

On the fifth day in culture, cells were washed and exposed to $100 \mu \mathrm{M}$ glutamate or $100 \mu \mathrm{M}$ kainate, at $37^{\circ} \mathrm{C}$, in $\mathrm{Na}^{+}$buffer with the following composition: $132 \mathrm{mM}$ $\mathrm{NaCl}, 4 \mathrm{mM} \mathrm{KCl}, 6 \mathrm{mM}$ glucose, $10 \mathrm{mM}$ HEPES, pH 7.4, in the presence of $1 \mathrm{mM} \mathrm{CaCl}$. When (+)-5-methyl10,11-dihydro-5H-dibenzo[a,d]cyclohepten-5,10-imine maleate (MK-801), 6-cyano-7-nitroquinoxaline-2,3-dione (CNQX), LY 303070 [the active isomer of 1-(4a minophenyl) -3-methylcarba my $1-4-$ methy $1-7,8-$ methylenedioxy-3,4-dihydro-5H-2,3-benzodiazepine; GYKI 53655], or cyclothiazide was used, a preincubation of 5 min was performed before stimulation with the agonists of the glutamate receptors. In the studies using the inhibitors of the MAPKs, a preincubation of $1 \mathrm{hr}$ was performed prior to stimulation with the glutamate receptor agonists.

To study the $\mathrm{Ca}^{2+}$ dependence of the activation of the transcription factor AP-1 induced by excitotoxic stimulation, the cells were washed and exposed in $\mathrm{Na}^{+}$buffer with the following composition: $132 \mathrm{mM} \mathrm{NaCl}, 4 \mathrm{mM} \mathrm{KCl}, 6 \mathrm{mM}$ glucose, $1 \mathrm{mM} \mathrm{MgCl}$, $0.5 \mathrm{mM}$ EGTA, $10 \mathrm{mM}$ HEPES, pH 7.4. The basal free calcium concentration in this buffer was $50 \mathrm{nM}$.

\section{Assessment of Neuronal Injury}

Cultures were exposed to the agonists of glutamate receptors, during $1 \mathrm{hr}$ at $37^{\circ} \mathrm{C}$, in the presence or not of other drugs, as indicated in the figures. After the incubation period, the stimulation media were removed and the cells were further washed in $\mathrm{Na}^{+}$buffer. The cells were returned to the incubation chamber in serum-free culture medium until assessment of neuronal injury, by a colorimetric assay for cell survival, using 3-(4,5-dimethylthiazol-2-yl)-2,5-diphenyl (MTT), or by analysis of the nuclear morphology. The MTT assay was a modification of the method of Mosmann (1983). MTT $(0.75 \mathrm{mg} / \mathrm{ml})$ in $\mathrm{Na}^{+}$buffer was added to the cultures and incubated for $3 \mathrm{hr}$ at $37^{\circ} \mathrm{C}$ in the incubation chamber. MTT when taken up by live cells is converted to a water-insoluble blue product. The precipitated dye was dissolved in $0.04 \mathrm{M} \mathrm{HCl}$ in isopropanol and colorimetrically (absorbance at $570 \mathrm{~nm}$ ) quantitated. All experiments were performed in triplicate.

The nuclear morphology of retina cells was analyzed by fluorescence microscopy of live cells using the DNA stains propidium iodide $(2 \mu \mathrm{g} / \mathrm{ml})$, which fluoresces red and enters cells only when the membrane presents ruptures, and Syto-13
(0.5 $\mu \mathrm{M})$, which fluoresces green and enters cells with intact cytoplasmatic membrane (Ankarcrona et al., 1995). Viable neurons display a normal nuclear size and green fluorescence. $\mathrm{Ne}-$ crotic neurons manifest red fluorescence without chromatin condensation, and apoptotic neurons display pyknotic nuclei with condensed or fragmented chromatin and fluoresce green. Secondary necrosis was also observed, with the nucleus displaying condensed or fragmented chromatin fluorescing red. These neurons were scored as apoptotic neurons, because the process of secondary necrosis may reflect an insufficient removal of apoptotic cells in in vitro systems, and in this case secondary processes may cause cell disintegration. Cells were examined and scored with a Nikon Diaphot TMD microscope. All experiments were performed in duplicate, and as a minimum 300 cells were scored for each coverslip.

\section{Preparation of Nuclear Extracts and Electophoretic Mobility Shift Assay}

Nuclear extracts were prepared either immediately after the excitotoxic stimulation or after incubation in culture medium lacking serum for the indicated poststimulation period. Cells were washed with ice-cold phosphate buffer $(137 \mathrm{mM}$ $\mathrm{NaCl}, 2.7 \mathrm{mM} \mathrm{KCl}, 10 \mathrm{mM} \mathrm{Na} \mathrm{HPO}_{4}, 1.8 \mathrm{mM} \mathrm{KH}_{2} \mathrm{PO}_{4}, \mathrm{pH}$ 7.4) and solubilized in buffer 1 [10 $\mathrm{mM}$ HEPES, $10 \mathrm{mM} \mathrm{NaCl}$, $3 \mathrm{mM} \mathrm{MgCl}_{2}, 0.1 \%$ Triton X-100, 1 mM EGTA, pH 7.5, $1 \mathrm{mM}$ dithiothreitol (DTT), $1 \mathrm{mM}$ phenylmethylsulfonyl fluoride (PMSF), $10 \mu \mathrm{M}$ trans-epoxysuccinyl-L-leucylamido-(4guanidino)butane (E64), $20 \mu \mathrm{g} / \mathrm{ml}$ benzamidine, and $25 \mu \mathrm{g} / \mathrm{ml}$ pepstatin A]. Cell clumps were scraped into Eppendorf tubes and incubated on ice for $40 \mathrm{~min}$. The nuclei were pelleted by centrifugation at $2,400 \mathrm{~g}$ for $10 \mathrm{~min}$ at $4{ }^{\circ} \mathrm{C}$ and resuspended in buffer 2 (25 mM HEPES, $300 \mathrm{mM} \mathrm{NaCl}, 5 \mathrm{mM} \mathrm{MgCl}_{2}, 1 \mathrm{mM}$ EGTA, 20\% glycerol, pH 7.4, 1 mM DTT, 1 mM PMSF, $10 \mu \mathrm{M}$ E64, $20 \mu \mathrm{g} / \mathrm{ml}$ benzamidine, and $25 \mu \mathrm{g} / \mathrm{ml}$ pepstatin A). After incubation on ice for $60 \mathrm{~min}$, the lysates were centrifuged at $12,000 \mathrm{~g}$ for $20 \mathrm{~min}$ at $4^{\circ} \mathrm{C}$. The supernatants (nuclear extracts) were collected and stored at $-70^{\circ} \mathrm{C}$ until use. Protein concentration of the extracts was measured using the BCA assay kit.

Double-stranded oligonucleotides with consensus binding motifs for the AP-1 and NF- $\mathrm{BB}$ transcription factors (AP-1, 5'-CGCTTGATGACTCAGCCGGAA- $3^{\prime}$; NF-кB, 5' AGTTGAGGGGACTTTCCCAGGC- $3^{\prime}$ ) were end-labelled with $\left[\gamma-{ }^{32} \mathrm{P}\right] \mathrm{ATP}$ with the T4 polynucleotide kinase and purified through a Sephadex G-50 spin column. Eight or twenty micrograms of nuclear proteins, for the DNA-binding assay of AP-1 or NF- $\mathrm{BB}$, respectively, were incubated for $30 \mathrm{~min}$ at room temperature in $20 \mu \mathrm{l}$ of binding reaction buffer $[20 \mathrm{mM}$ HEPES, $50 \mathrm{mM} \mathrm{KCl,} 1 \mathrm{mM} \mathrm{MgCl}_{2}, 0.5 \mathrm{mM}$ DTT, 4\% Ficoll, $2 \mu \mathrm{g}$ poly(dIdC), $20 \mu \mathrm{g}$ bovine serum albumin (BSA), $\mathrm{pH}$ 7.9] with $150,000 \mathrm{cpm}$ of $\left[\gamma_{-}{ }^{32} \mathrm{P}\right]$-labelled oligonucleotide probe. The DNA-protein complexes were resolved by electrophoresis on $4 \%$ native polyacrylamide gels. The electrophoresis was performed in TBE buffer $(44.5 \mathrm{mM}$ boric acid, $44.5 \mathrm{mM}$ Tris, $1 \mathrm{mM}$ EDTA, pH 8.0). After drying, the DNA-protein complexes in the gel were visualized by autoradiography. For supershift analysis, $8 \mu \mathrm{g}$ of nuclear extracts were incubated on ice for $2 \mathrm{hr}$ with $1.5 \mu \mathrm{g}$ of antibodies before the addition of the radiolabelled oligonucleotide. Specificity of binding was assessed 
by competition with a 100-fold excess of unlabelled oligonucleotide probe. The scanned digital images were quantified using ImageQuant software (Molecular Dynamics).

\section{Western Blot Assay}

Retinal cells in culture were solubilized and sonicated in a buffer solution containing $50 \mathrm{mM}$ HEPES, $150 \mathrm{mM} \mathrm{NaCl}, 1 \%$ Triton X-100, 2 mM EGTA, 2 mM EDTA, $2 \mathrm{mM} \mathrm{Na} \mathrm{VO}_{4}$, $50 \mathrm{mM} \mathrm{NaF}, \mathrm{pH}$ 7.4, 1 mM DTT, 1 mM PMSF, $10 \mu \mathrm{M}$ E64, $20 \mu \mathrm{g} / \mathrm{ml}$ benzamidine, and $25 \mu \mathrm{g} / \mathrm{ml}$ pepstatin A. The lysates were centrifuged at $12,000 \mathrm{~g}$ for $20 \mathrm{~min}$ at $4^{\circ} \mathrm{C}$, the supernatant was collected, and the protein concentration was determined using the BCA assay kit. Thirty micrograms of protein were resolved by sodium dodecyl sulfate-polyacrilamide gel electrophoresis (SDS-PAGE) on 12\% polyacrilamide gels and electroblotted onto polyvinylidene difluoride (PVDF) membranes. After blocking in $0.5 \%$ milk/0.1\% Tween 20 in TBS $(20 \mathrm{mM}$ Tris, $137 \mathrm{mM} \mathrm{NaCl}, \mathrm{pH} \mathrm{7.6)}$, the membranes were probed during $1 \mathrm{hr}$ with the antiphospho-ERK antibody $(1: 5,000)$ in blocking buffer. After multiple washes (five times for $5 \mathrm{~min}$ each with blocking buffer) membranes were incubated with 1:10,000 alkaline phosphatase-conjugated anti-rabbit $\operatorname{IgG}$ in blocking buffer for $1 \mathrm{hr}$. After additional washes $(5 \times 5$ minutes $)$ in the blocking buffer, membranes were processed with ECF chemifluorescence substrate (Amersham) for $5 \mathrm{~min}$. The membranes were dried between filter papers, and scanned in Storm 860 (Molecular Dynamics). The phosphorylation-specific antibody was stripped off the membranes by incubation in $62.5 \mathrm{mM}$ Tris, $\mathrm{pH} 6.7,2 \% \mathrm{SDS}$, and $100 \mathrm{mM} 2$-mercaptoethanol at $50^{\circ} \mathrm{C}$ for $30 \mathrm{~min}$. The membranes were then reprobed with anti- $\alpha-$ tubulin antibody $(1: 1,500)$ to control for protein loading.

\section{Other Methods}

Results are presented as means \pm SEM of the number of experiments indicated. Statistical significance was determined by ANOVA analysis followed by the Dunnett's and/or Bonferroni's tests.

\section{RESULTS}

\section{Glutamate Receptor Overstimulation Induces Retinal Neuron Death}

Primary cultures of chick retinal neurons, enriched in amacrine-like cells (Santos et al., 1998), were challenged for $1 \mathrm{hr}$ at $37^{\circ} \mathrm{C}$ with $100 \mu \mathrm{M}$ glutamate, or $100 \mu \mathrm{M}$ kainate, in $\mathrm{Mg}^{2+}$-free sodium buffer with $1 \mathrm{mM}$ of $\mathrm{Ca}^{2+}$. The cell viability, determined $20-22 \mathrm{hr}$ after stimulation using the MTT assay, was reduced (Fig. 1A), and fragmentation of the neurites could be observed by phase-contrast microscopy $1 \mathrm{hr}$ after stimulation (not shown). As shown in Figure 1A, stimulation of retinal neurons with glutamate or kainate decreased cell viability by $25.5 \%$ or $44.1 \%$, respectively. Under these experimental conditions, kainate was a more potent toxin than glutamate.

The toxicity induced by the glutamate receptor agonists was reverted by the antagonists of the ionotropic glutamate receptors. As can be observed in Figure 1A, the decrease in cell viability induced by glutamate was com-
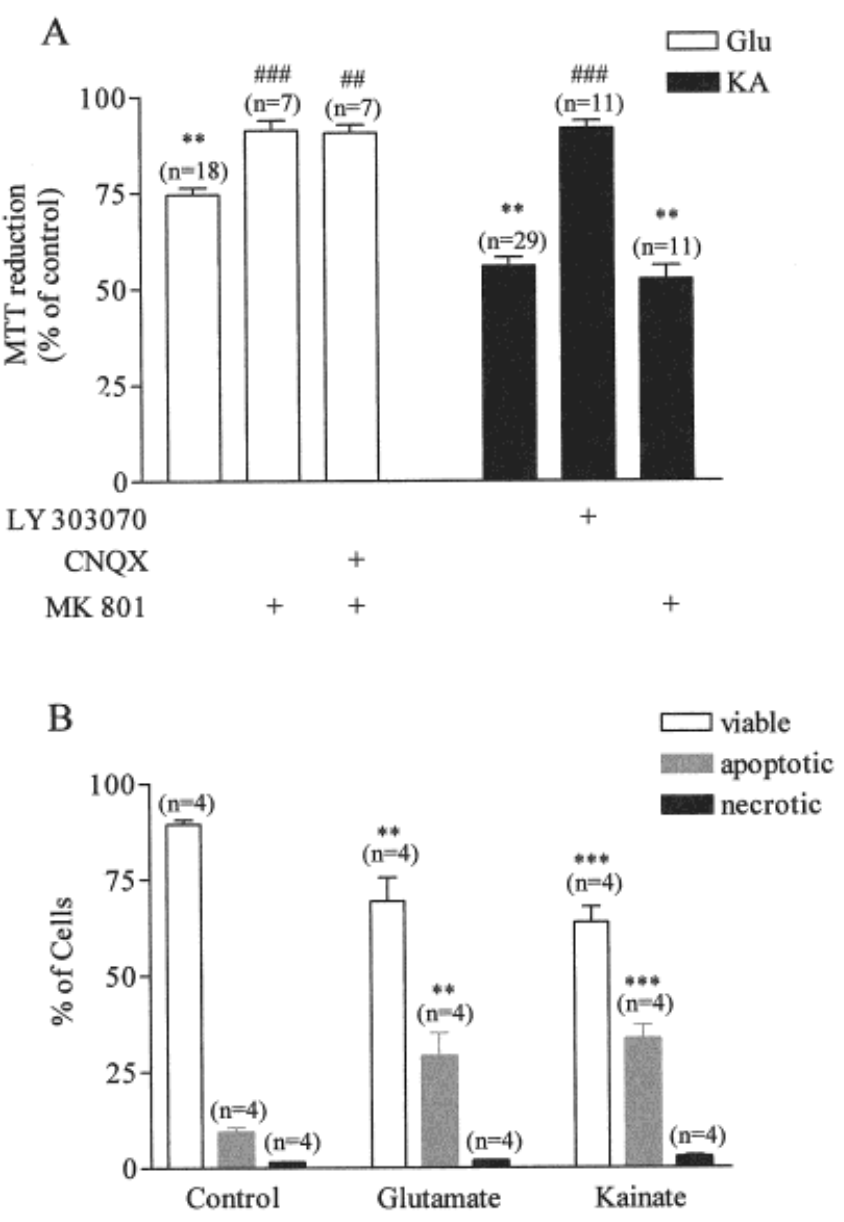

Fig. 1. Glutamate and kainate induce retinal cell death through activation of different receptors. A: Cells were exposed for $1 \mathrm{hr}$ to $100 \mu \mathrm{M}$ glutamate or $100 \mu \mathrm{M}$ kainate in $\mathrm{Mg}^{2+}$-free sodium buffer with $1 \mathrm{mM}$ $\mathrm{Ca}^{2+}$, with or without the glutamate receptor antagonists. A preincubation of $5 \mathrm{~min}$ was carried out with the glutamate receptor antagonists. After a washing step, the cells were returned to the incubator chamber for 20-22 hr in serum-free culture medium, and cell viability was assessed by the MTT assay as described in Materials and Methods. Control cells were incubated under conditions identical to those of cells submitted to excitotoxic stimulation but in the absence of drugs, and their MTT value was taken as $100 \%$ for each preparation $(100 \% \pm$ $5.83 \%, \mathrm{n}=30)$. Bars represent mean \pm SEM values of the indicated number of experiments performed in triplicate in independent preparations. Asterisks indicate significant difference from control; pound signs indicate significant difference from glutamate agonists (two symbols, $P<0.01$; three symbols, $P<0.001)$. B: Retinal neuron death induced by glutamate or kainate is apoptotic. Cells were exposed for $1 \mathrm{hr}$ to $100 \mu \mathrm{M}$ glutamate or $100 \mu \mathrm{M}$ kainate in $\mathrm{Mg}^{2+}$-free sodium buffer with $1 \mathrm{mM} \mathrm{Ca}^{2+}$. After a wash step, the cells were returned to the incubator chamber for $5 \mathrm{hr}$ in serum-free culture medium. Control cells were incubated in $\mathrm{Mg}^{2+}$-free sodium buffer with $1 \mathrm{mM} \mathrm{Ca}^{2+}$ without drugs. The cells were then incubated with $0.5 \mu \mathrm{M}$ Syto- 13 and $2 \mu \mathrm{g} / \mathrm{ml}$ propidium iodide (PI) in saline buffer to visualize nuclei morphology and were scored with a fluorescence microscope. Bars represent mean \pm SEM values of the indicated number of experiments

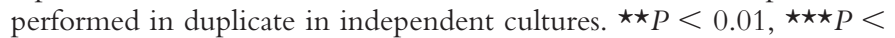
0.001 vs. control. 
pletely reverted by $10 \mu \mathrm{M}$ MK-801, a selective antagonist for the NMDA receptors, without any additional protective effect of $20 \mu \mathrm{M}$ CNQX, an antagonist of the nonNMDA ionotropic glutamate receptors, suggesting that glutamate toxicity is essentially mediated by the NMDA receptors. The toxicity induced by kainate was completely reverted by the 2,3-benzodiazepine LY 303070 (15 $\mu \mathrm{M})$, which is the active isomer of the noncompetitive AMPA receptor antagonist GYKI 53655 (Donevan and Rogawski, 1993; Paternain et al., 1995). MK-801 (10 $\mu \mathrm{M})$ was without any protective effect, suggesting that in this case the toxicity was mediated only through the activation of the AMPA receptors (Fig. 1A). The antagonists of the ionotropic glutamate receptors were without toxic effect under our experimental conditions (data not shown).

To determine whether retinal neurons die by apoptosis or necrosis upon excitotoxic stimulation, we analyzed the nuclear morphology of cells challenged for $1 \mathrm{hr}$ at $37^{\circ} \mathrm{C}$ with $100 \mu \mathrm{M}$ of glutamate or $100 \mu \mathrm{M}$ of kainate in $\mathrm{Mg}^{2+}$-free sodium buffer with $1 \mathrm{mM}$ of $\mathrm{Ca}^{2+}$. Five hours after stimulation, retinal neurons were loaded with the DNA stains propidium iodide and Syto 13, and the nuclear morphology was observed by fluorescence microscopy. Control cultures of neuronal retina cells had about $9.3 \% \pm 1.3 \%$ dead cells, with condensed and/or fragmented chromatin in pyknotic nuclei. Cells with this type of morphology were scored as apoptotic neurons (Fig. 1B). In control cultures, about $1.4 \%$ of necrotic cells were also present. In retinal neurons exposed to excitotoxic stimuli, there was a significant increase in the number of neurons displaying condensed and/or fragmented chromatin in pyknotic nuclei, suggesting that retinal neurons exposed to the glutamate agonists die by apoptosis. Cultures stimulated with glutamate or kainate displayed about $29.0 \% \pm 6.1 \%$ or $33.4 \% \pm 3.7 \%$ of cells with apoptoticlike morphology, respectively. The number of necrotic cells did not increase significantly in cultures exposed to the excitotoxic stimuli.

We studied whether desensitisation of the AMPA receptors could influence the glutamate-induced toxicity in cultured retinal neurons using cyclothiazide, an inhibitor of AMPA receptor desensitisation. In the presence of $30 \mu \mathrm{M}$ cyclothiazide, there was a significant increase in the toxicity induced by $100 \mu \mathrm{M}$ glutamate, which reached a level similar to that observed with kainate. Under these experimental conditions, the MTT reduction was about $51.5 \%$ relative to the control (Fig. 2). Our results show that, in the presence of cyclothiazide, the glutamate-induced toxicity is mediated essentially through the AMPA receptors, because $73.5 \%$ of toxicity was reverted by LY 303070. However, a contribution of the NMDA receptors was also observed; we were able to revert $91.2 \%$ of the toxicity when the excitotoxic stimulation was performed in the presence of LY 303070 plus MK-801, even though MK-801 alone could not decrease the toxic effect of glutamate. Cyclothiazide was without toxic effect under our experimental conditions (data not shown).

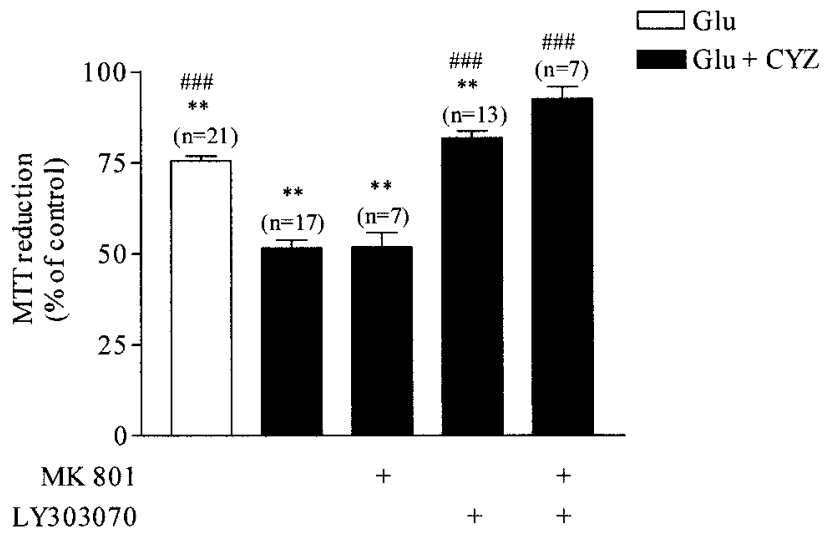

Fig. 2. Effect of AMPA receptor desensitization. Cells were exposed for $1 \mathrm{hr}$ to $100 \mu \mathrm{M}$ glutamate in the presence or in the absence of 30 $\mu \mathrm{M}$ cyclothiazide, with or without the glutamate receptor antagonists. After a washing step, the cells were returned to the incubator chamber for $20-22 \mathrm{hr}$ in serum-free culture medium, and cell viability was assessed by the MTT assay as described in Materials and Methods. Cells were exposed to the drugs in $\mathrm{Mg}^{2+}$-free sodium buffer with $1 \mathrm{mM}$ $\mathrm{Ca}^{2+}$. A preincubation of $5 \mathrm{~min}$ was carried out with the glutamate receptor antagonists and cyclothiazide. Control cells were incubated under conditions identical to those of cells submitted to excitotoxic stimulation but in the absence of drugs, and their MTT value was taken as $100 \%$ for each preparation $(100 \% \pm 5.83 \%, \mathrm{n}=30)$. Bars represent mean \pm SEM values of the indicated number of experiments performed in triplicate in independent cultures. Asterisks indicate significant difference from control; pound signs indicate significant difference from glutamate plus cyclothiazide (two symbols, $P<0.01$; three symbols, $P<0.001)$.

\section{AP-1 DNA-Binding Activity Increases Upon Retinal Neuron Stimulation With Glutamate or Kainate}

Retinal neurons were exposed to $100 \mu \mathrm{M}$ of glutamate or $100 \mu \mathrm{M}$ of kainate for $1 \mathrm{hr}$ at $37^{\circ} \mathrm{C}$ in $\mathrm{Mg}^{2 \text { s }}$-free sodium buffer with $1 \mathrm{mM}$ of $\mathrm{Ca}^{2+}$. Nuclear extracts were prepared immediately after stimulation or after incubation at $37^{\circ} \mathrm{C}$ in $\mathrm{BME}$ without serum for different periods, as indicated. To determine the AP-1 DNA-binding activity, $8 \mu \mathrm{g}$ of nuclear protein were incubated with a radiolabelled oligonucleotide containing the consensus binding motif for the transcription factor AP-1 and were analyzed by electrophoretic mobility shift assay (EMSA; Fig. 3A). Excitotoxic stimulation caused an increase in the AP-1 DNA-binding activity, which was maximal $2 \mathrm{hr}$ after stimulation. Glutamate induced a greater increase in the AP-1 DNA-binding activity than kainate (Fig. 3A,B). The antagonists of the ionotropic glutamate receptors (MK801 plus CNQX and LY 303070) caused a nonspecific increase of AP-1 activity on their own. Therefore, we could not test whether glutamate receptor antagonists revert the increase of AP-1 activity induced by glutamate and kainate.

To determine the specificity of AP-1 activation by glutamate and kainate, we studied the calcium dependence of the enhancement of the AP-1 DNA-binding activity 
A
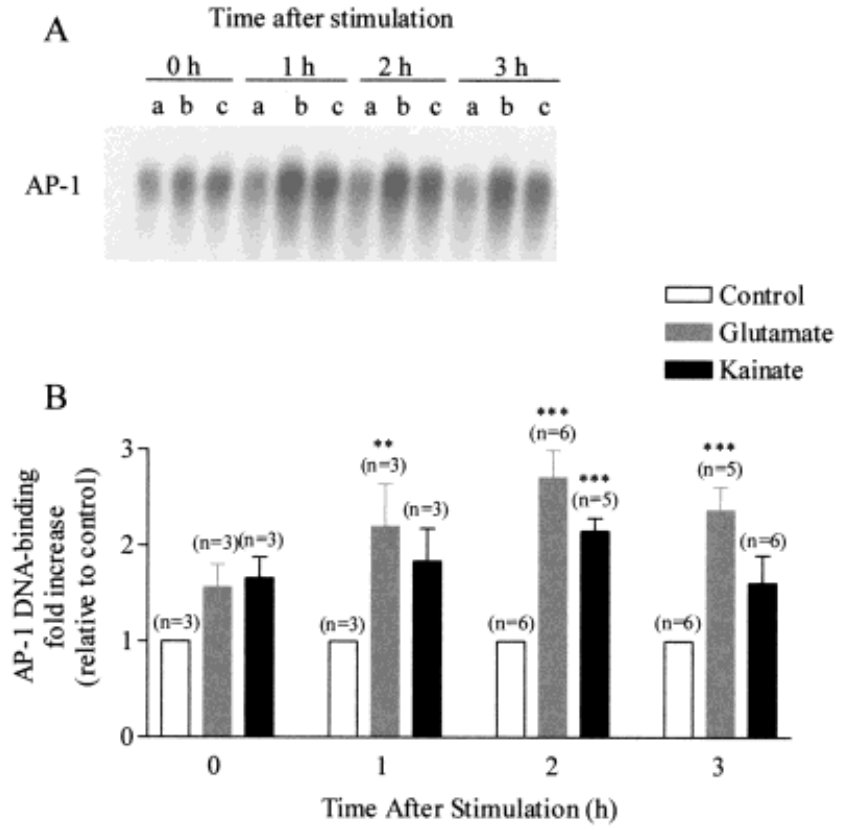

C

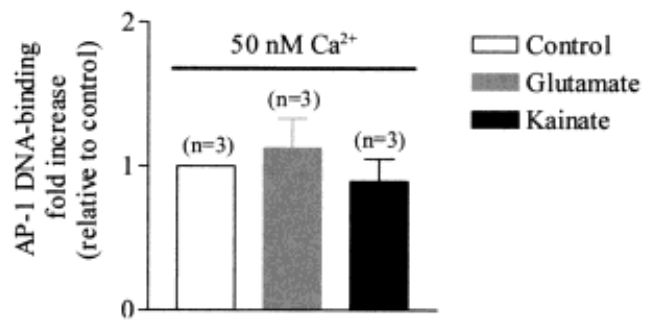

Fig. 3. AP-1 DNA-binding activity is increased in retinal neurons stimulated with glutamate or kainate. A: Representative autoradiogram showing a time course of the DNA-binding activity of AP-1 in retinal neurons exposed for $1 \mathrm{hr}$ to $100 \mu \mathrm{M}$ glutamate (b) or $100 \mu \mathrm{M}$ kainate (c) in $\mathrm{Mg}^{2+}$-free sodium buffer with $1 \mathrm{mM} \mathrm{Ca}^{2+}$. Control cells (a) were incubated in $\mathrm{Mg}^{2+}$-free sodium buffer with $1 \mathrm{mM} \mathrm{Ca}^{2+}$ without drugs. The nuclear extracts were prepared immediately after stimulation or 1,2, or $3 \mathrm{hr}$ after stimulation. Eight micrograms of nuclear protein were used for EMSA. B: Quantification of the AP-1 DNA-binding activity of retinal neurons stimulated as described for A using ImageQuant software (Molecular Dynamics). C: Calcium dependence of glutamate receptor agonists-induced activation of AP-1. Retinal neurons were exposed for $1 \mathrm{hr}$ to $100 \mu \mathrm{M}$ glutamate or $100 \mu \mathrm{M}$ kainate in sodium buffer with a composition of $132 \mathrm{mM} \mathrm{NaCl}, 4 \mathrm{mM} \mathrm{KCl}$, $6 \mathrm{mM}$ glucose, $1 \mathrm{mM} \mathrm{MgCl} 2,0.5 \mathrm{mM}$ EGTA, $10 \mathrm{mM}$ HEPES, $\mathrm{pH}$ 7.4 , and a basal free calcium concentration of $50 \mathrm{nM}$. The nuclear extracts were prepared $2 \mathrm{hr}$ after the stimulation period, and AP-1 DNA-binding activity was examined by EMSA. Bars represent mean \pm SEM values of the indicated number of experiments performed in independent cultures. ${ }^{\star} \times P<0.01,{ }^{\star}{ }^{\star} P P<0.001$ vs. control.

induced by excitotoxic stimulation of chick retinal neurons (Fig. 3C). Cells were exposed for $1 \mathrm{hr}$ at $37^{\circ} \mathrm{C}$ to $100 \mu \mathrm{M}$ of glutamate or $100 \mu \mathrm{M}$ of kainate in sodium buffer with a free calcium concentration of $50 \mathrm{nM}$. When cells were exposed to excitotoxic stimulation in the ab- sence of calcium, none of the glutamate agonists could induce an increase in the AP-1 DNA-binding activity.

Because the AP-1 complex can be constituted by different Fos and Jun family members, we investigated the composition of the transcription factor following excitotoxic stimulation. Supershift experiments with several antibodies directed against different Fos and Jun proteins were performed to determine the contribution of each protein to the AP-1 DNA-binding activity in retinal neurons (Fig. 4). In control neurons a faint supershift was detected with the c-Fos antibody, which reacts with all members of the Fos family, and there was a decrease on the specific band of AP-1 DNA binding (Fig. 4). The supershift with this antibody became more evident in nuclear extracts from neurons exposed to excitotoxic stimulation. We also observed a supershift with the antibody against Fra-2 in extracts from control and stimulated neurons (Fig. 4). When we used the antibody against Fos B, we did not observe either a supershift or a decrease in the specific band for AP-1 DNA binding under either control or stimulated conditions. The absence of an effect with the Fos B antibody is not due to a lack of reactivity with our biological preparation; we observed a specific band for Fos $\mathrm{B}$, using the same antibody, in a Western blot assay (data not shown). Additionally, we detected a supershift with the antibodies for c-Jun and Jun D and a decrease in the specific band of AP-1 DNA binding under both control and stimulated conditions. When the antibodies against Jun B and ATF 2 were used, a decrease in the specific band of AP-1 DNA binding in both control and stimulated situations was detected. The antibodies against Jun B and ATF 2 may block the DNA-binding site of these proteins. In that case, the decrease in the specific AP-1 DNA binding observed with those antibodies would suggest the participation of these proteins in the AP- 1 complex. The results show that the AP-1 complex includes proteins of the Fos family, namely, Fra-2, and of the Jun family, namely, c-Jun and Jun D. Jun B and ATF 2 may also participate in the complex. In cultured amacrine neurons, for the stimulation conditions used, Fos B is not present in the AP-1 complexes. The pattern of AP-1 protein composition induced by excitotoxic stimulation was similar to the pattern observed for control neurons. Furthermore, we did not observe differences in the pattern of AP-1 proteins for the complexes present on retinal neurons 1,2 , or $3 \mathrm{hr}$ after stimulation (data not shown).

\section{Excitotoxic Stimulation of Retinal Neurons Does Not Change NF-KB DNA-Binding Activity}

We also studied whether the excitotoxic stimulation of retinal neurons could induce the activation of the NF- $\kappa \mathrm{B}$ transcription factor, which is sensitive to intracellular stress in many systems (Tong et al., 1998). Cells were stimulated with $100 \mu \mathrm{M}$ glutamate or $100 \mu \mathrm{M}$ kainate for $15,30,60$, or $120 \mathrm{~min}$, and the nuclear extracts were prepared immediately after the stimuli. With our preparation of retinal neurons, we did not observe a significant increase in the DNA-binding activity of NF- $\kappa \mathrm{B}$, either with glutamate or with kainate stimulation (Fig. 5). 

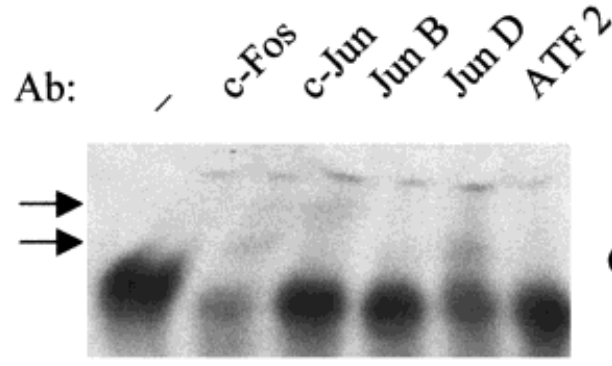

Control

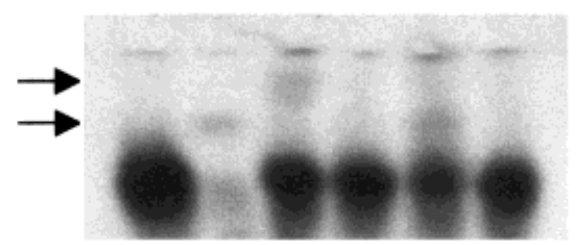

Glutamate

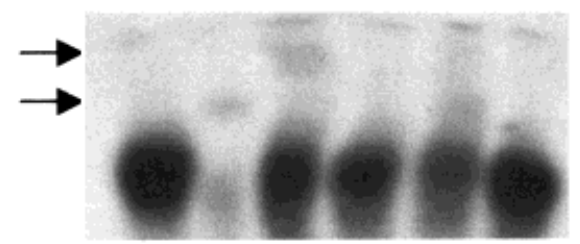

Kainate

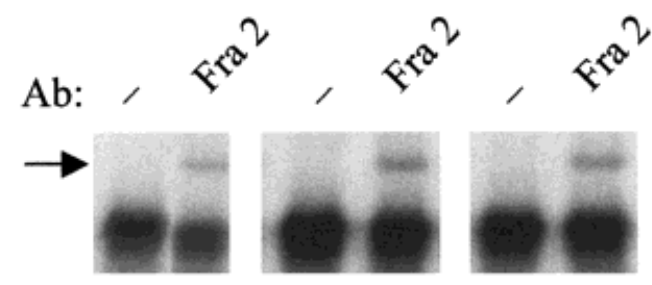

Control Glutamate Kainate

Fig. 4. Subunit composition of AP-1 dimers in cultured neuronal retina cells. Representative autoradiogram showing the supershift of the AP-1 subunits of retinal neurons exposed for $1 \mathrm{hr}$ to $100 \mu \mathrm{M}$ glutamate or $100 \mu \mathrm{M}$ kainate in $\mathrm{Mg}^{2+}$-free sodium buffer with $1 \mathrm{mM} \mathrm{Ca}^{2+}$. Control cells were incubated in $\mathrm{Mg}^{2+}$-free sodium buffer with $1 \mathrm{mM}$ $\mathrm{Ca}^{2+}$ without drugs. The nuclear extracts were prepared $2 \mathrm{hr}$ after the stimulation period. Eight micrograms of nuclear protein were incubated with $1.5 \mu \mathrm{g}$ of antibody (Ab) for $2 \mathrm{hr}$ at $4^{\circ} \mathrm{C}$ before incubation with the radiolabelled oligonucleotide. Arrows indicate positions of the bands representing antibody-protein-DNA complexes.

\section{Glutamate and Kainate Increased the ERK Activity}

Previous work in cultured rat hippocampal neurons and in rat striatal neurons has shown that neuronal ERK can be activated upon glutamatergic stimulus, in a calcium-dependent manner (Bading and Greenberg, 1991; Schwarzschild et al., 1999). Furthermore, ERK can regulate the expression of some of the proteins present on the AP-1 complex (Karin, 1995). Therefore, we investigated whether the activation of ionotropic glutamate receptors on cultured chick retinal neurons induces the activation of

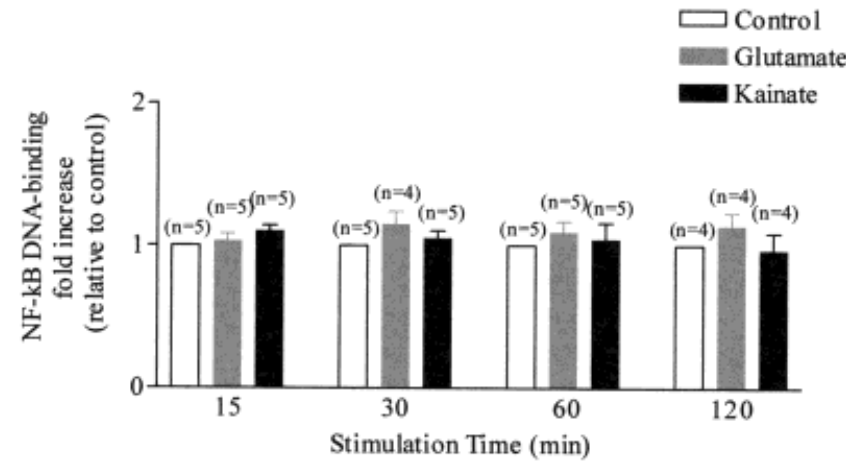

Fig. 5. NF-кB DNA-binding activity of retinal neurons stimulated with glutamate or kainate. Retinal neurons were exposed to $100 \mu \mathrm{M}$ glutamate or $100 \mu \mathrm{M}$ kainate in $\mathrm{Mg}^{2+}$-free sodium buffer with $1 \mathrm{mM}$ $\mathrm{Ca}^{2+}$ for the indicated times. Control cells were incubated in $\mathrm{Mg}^{2+}$ free sodium buffer with $1 \mathrm{mM} \mathrm{Ca}^{2+}$ without drugs. The nuclear extracts were prepared immediately after stimulation, and $20 \mu \mathrm{g}$ of nuclear protein were used for EMSA. The quantification of NF- $\kappa \mathrm{B}$ DNA-binding activity was performed using ImageQuant software (Molecular Dynamics). Bars represent mean \pm SEM values of the indicated number of experiments performed in independent preparations.

ERK. In previous studies in our laboratory, it was shown that in cultured chick retinal neurons stimulation of the ionotropic glutamate receptors leads to an increase in the intracellular free calcium concentration (Duarte et al., 1996; Carvalho et al., 1998). Cultured cells were exposed to $100 \mu \mathrm{M}$ glutamate or $100 \mu \mathrm{M}$ kainate, and total extracts were prepared 2 or $5 \mathrm{~min}$ after stimulation. We observed that, in retinal neurons, 2 min of stimulation with either glutamate or kainate was sufficient to increase the phosphorylation of ERK (Fig. 6), indicative of ERK activation. The increase of ERK phosphorylation was greater in neurons stimulated with kainate.

\section{Effect of the MAPKs Inhibitors on the Neuronal Cell Death}

Because glutamate and kainate activate ERK in retinal neurons, we investigated the contribution of the MAPK pathway to the excitotoxic response. Retinal neurons were preincubated for $1 \mathrm{hr}$ with the MEK inhibitors $20 \mu \mathrm{M}$ PD 98059 and 250 nM U 0126 (Favata et al., 1998; Encinas et al., 1999) and then challenged for $1 \mathrm{hr}$ with $100 \mu \mathrm{M}$ glutamate or $100 \mu \mathrm{M}$ kainate in the presence of the MEK inhibitors. After stimulation, cells were washed and incubated 20-22 hr in BME without serum before the MTT assay was performed. The inhibition of MEK did not change the toxicity induced by glutamate (Fig. 7A) but increased the toxicity induced by kainate (Fig. 7B). These results suggest that the MAPK pathway normally contributes to the survival of retinal neurons exposed to kainate. When cells were preincubated with the p38 inhibitor SB $203580(10 \mu \mathrm{M}$; Kawasaki et al., 1997), no change was observed in the excitotoxic response to either glutamate or kainate (Fig. 7). We did not observe 


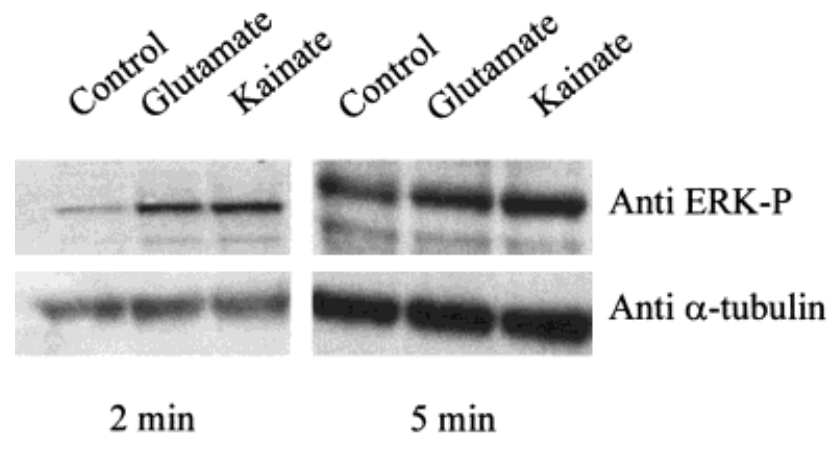

Fig. 6. ERK activation in retinal neurons stimulated with glutamate and kainate. Retinal neurons were incubated with or without $100 \mu \mathrm{M}$ glutamate or $100 \mu \mathrm{M}$ kainate in $\mathrm{Mg}^{2+}$-free sodium buffer with $1 \mathrm{mM}$ $\mathrm{Ca}^{2+}$ for the indicated times. Control cells were incubated in $\mathrm{Mg}^{2+}$ free sodium buffer with $1 \mathrm{mM} \mathrm{Ca}^{2+}$ without drugs. Total cell extracts were prepared immediately after stimulation. Thirty micrograms of total proteins were used for immunoblot analysis with an antiphosphoERK antibody. The membrane was reprobed with an antibody, anti$\alpha$-tubulin, to confirm an equal amount of protein loading in each gel lane. The experiments were performed in two independent preparations.

any toxic effects of the MAPKs inhibitors (data not shown).

\section{DISCUSSION}

The data presented show that, in chick embryo retinal neurons, the overstimulation of different ionotropic glutamate receptors triggers different intracellular signaling cascades. It was previously observed in our laboratory that in cultured amacrine-like cells, for small equivalent $\mathrm{Ca}^{2+}$ loads, the $\mathrm{Ca}^{2+}$ influx through the NMDA receptorassociated channel and through the AMPA receptorassociated channel triggers cell death to different extents (Ferreira et al., 1996), which suggests that different ionotropic glutamate receptors could be activating different signaling pathways upon excitotoxic stimuli. Accordingly, in the present work, we observed that stimulation of different ionotropic glutamate receptors induces different levels of toxicity. Stimulation of retinal neurons with either glutamate or kainate increased ERK phosphorylation, but only kainate-induced ERK activation was correlated with the activation of a survival signaling pathway. In contrast, glutamate induces a greater increase in the AP-1 DNA-binding activity than kainate.

\section{Neurotoxicity Caused by Glutamate and Kainate in Cultured Retinal Neurons}

In the present paper, we report a decrease in cell viability of cultured retinal neurons exposed to excitotoxic stimuli. The ionotropic glutamate receptor type mediating the toxic effect depends on the glutamate receptor agonist used. We observed that the toxicity induced by glutamate was mediated essentially through the NMDA receptors, because it could be completely reverted by MK-801, a selective noncompetitive antagonist of the NMDA recep-

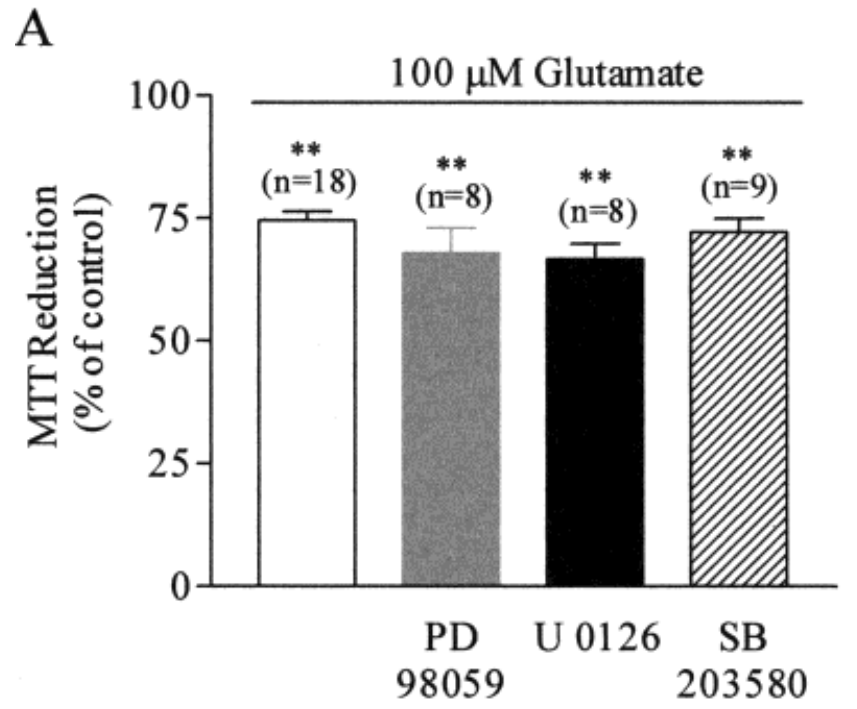

B

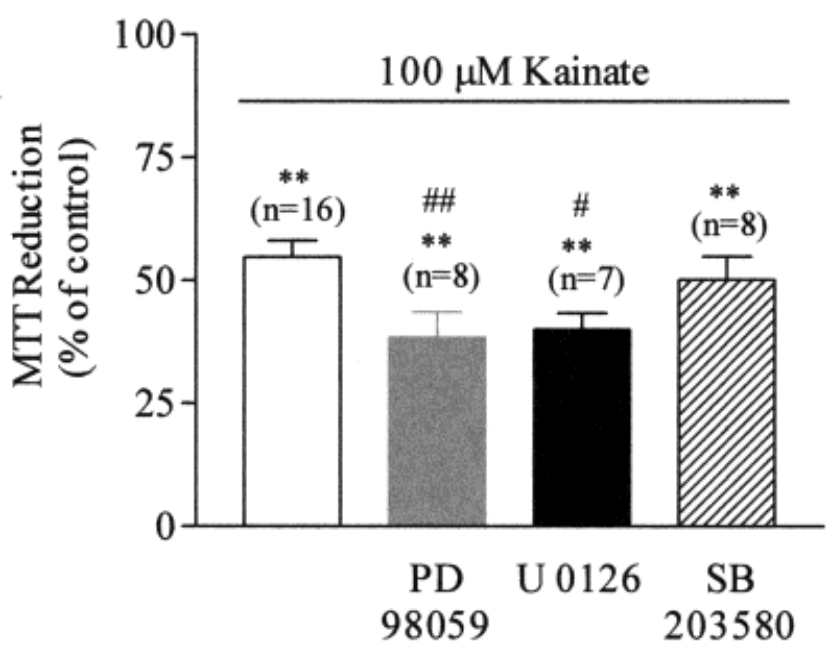

Fig. 7. Effect of the MAPK inhibitors on neuronal cell death. Retinal neurons were exposed for $1 \mathrm{hr}$ to $100 \mu \mathrm{M}$ glutamate (A) or $100 \mu \mathrm{M}$ kainate $(\mathbf{B})$ in $\mathrm{Mg}^{2+}$-free sodium buffer with $1 \mathrm{mM} \mathrm{Ca}^{2+}$. The cells were preincubated for $1 \mathrm{hr}$ in saline buffer with or without the MAPKs inhibitors $20 \mu \mathrm{M}$ PD 98059, $250 \mathrm{nM}$ U0126, and $10 \mu \mathrm{M}$ SB 203580. The MAPKs inhibitors were also present during the stimulation with glutamate agonists. Cell viability was assessed using the MTT assay. Control cells were incubated in $\mathrm{Mg}^{2+}$-free sodium buffer with $1 \mathrm{mM}$ $\mathrm{Ca}^{2+}$ without drugs, and their MTT value was taken as $100 \%$ for each preparation $(100 \% \pm 5.83 \%, \mathrm{n}=30)$. Bars represent mean \pm SEM values of the indicated number of experiments performed in triplicate in independent cultures. Asterisks indicate significant difference from control, pound signs indicate significant difference from glutamate agonists (one symbol, $P<0.05$; two symbols, $P<0.01$ ).

tors, without additional protective effect of CNQX, a competitive inhibitor of the AMPA/kainate receptors. With other neuronal systems, such as rat hippocampal neurons (Moudy et al., 1994) and rat cerebellar granule 
cells (Cebers et al., 1997), it was also observed that glutamate-induced toxicity may be entirely mediated through NMDA receptors.

In cultured chick retinal neurons, excitotoxic stimulation with kainate induced a greater reduction of cell viability than stimulation with glutamate. The kainateinduced toxicity was mediated through AMPA receptors; it was completely blocked by LY 303070, and MK-801 was without effect on the MTT reduction by cells stimulated with kainate, excluding a contribution of the NMDA receptors. We have previously reported that, in cultured chick retinal neurons, kainate stimulates ${ }^{45} \mathrm{Ca}^{2+}$ uptake and decreases MTT reduction in an LY 303070sensitive manner, which indicates that AMPA receptors are involved in kainate excitotoxicity (Ferreira et al., 1998). Other studies, in intact chick embryo retinas, showed that the toxicity induced by kainate is blocked by antagonists of the non-NMDA receptors, but not by MK801 (Chen et al., 1999). These studies and our work point to the relevance of neuronal retina cells as a model to study toxicity mediated by AMPA receptors. The contribution of AMPA receptors to the toxicity induced by kainate has also been observed in other neuronal systems, such as embryonic rat hippocampal cultures (Ohno et al., 1997; Ambrósio et al., 2000) and cultured murine neocortical neurons (Jensen et al., 1999).

Glutamate and kainate treatment of cultured neuronal retina cells, essentially of the amacrine type, caused cell death with morphological characterisitcs of apoptosis, namely, an increase in the number of neurons presenting condensed and/or fragmented chromatin in pyknotic nuclei. Previous studies in rabbit or rat retina showed that kainate or NMDA induces cell death through apoptosis (Perez et al., 1997; Lam et al., 1999; Kwong and Lam, 2000), and activation of caspases was detected upon ischemia-reperfusion in the retina (Katai and Yoshimura, 1999).

\section{Blockade of AMPA Receptor Desensitisation Increases the Excitotoxicity Caused by Glutamate}

Activation of AMPA receptors, when AMPA or glutamate is used as an agonist, elicits a rapid and strong desensitisation of the receptor. However, kainate induces an unusually rapid but much weaker desensitisation, and, as a result, whole-cell currents induced by kainate appear nondesensitising (Patneau et al., 1993; Hollmann and Heinemann, 1994; Bettler and Mulle, 1995; Yamada, 1998). We show that, in the presence of cyclothiazide, the glutamate-induced toxicity increases to a level identical to that reached by kainate excitotoxic stimulation of cultured retinal neurons. Additionally, our results show that, in the presence of cyclothiazide, the glutamate-induced toxicity is mediated essentially through AMPA receptors, although a contribution of NMDA receptors was also observed; we obtained greater neuroprotection when MK-801 was added together with LY 303070, even though MK-801 alone could not decrease toxicity. The involvement of the NMDA receptors in the toxic response to glutamate when AMPA desensitisation is blocked could be due to a direct action of the agonist on the NMDA receptor and to an indirect component of AMPA receptor toxicity, which would involve activation of the NMDA receptor as a consequence of glutamate being released from neurons by AMPA receptor-mediated depolarization.

In cultured retinal neurons, a correlation between the $\mathrm{Ca}^{2+}$ influx through the NMDA and AMPA/kainate receptor-associated channels and cell death was established (Ferreira et al., 1996). Furthermore, in retinal neurons, cyclothiazide enhanced both the ${ }^{45} \mathrm{Ca}^{2+}$ uptake and the neurotoxicity induced by AMPA (Ferreira et al., 1998). Additionally, in our preparation of cultured retinal neurons, containing essentially amacrine-like cells, highly $\mathrm{Ca}^{2+}$-permeable AMPA receptors are expressed (Duarte et al., 1996, 1998; Carvalho et al., 1998), enriched in the GluR3 and GluR4 subunits (A.L. Carvalho and C.B. Duarte, unpublished observations). These observations suggest that the increased glutamate toxicity that we observed in the presence of cyclothiazide is probably due to an increase in the intracellular $\mathrm{Ca}^{2+}$ concentration. In previous work with rat hippocampal neurons (Moudy et al., 1994), rat cerebellar granule neurons (Cebers et al., 1997), and human NT2-N neurons (Itoh et al., 1998), it was shown that cyclothiazide greatly enhances the glutamate-induced toxicity, essentially through activation of the AMPA receptors. A relationship between the increase in $\left[\mathrm{Ca}^{2+}\right]_{i}$, measured in single cerebellar granule cells, and an enhancement of the toxicity induced by glutamate following a blockade of AMPA receptor desensitization, in the presence of NMDA receptor blockers, was previously reported (Cebers et al., 1997). Our results provide further support for the notion that AMPA receptors may play a significant role in the neurotoxic effects produced by glutamate or kainate in retinal neurons.

\section{Activation of the AP-1 Transcription Factor by Excitotoxic Stimulation of Retinal Neurons}

We provide evidence that, in primary cultures of chick embryo retinal neurons, enriched in amacrine cells, overstimulation of glutamate receptors significantly increases the DNA-binding activity of AP-1 but not the DNA-binding activity of NF- $\mathrm{BB}$, two transcription factors sensitive to the intracellular redox conditions. In other neuronal systems, glutamate receptor activation was shown to enhance the AP-1 DNA-binding activity, but not NF- $\kappa \mathrm{B}$ DNA-binding activity. In cultured rat forebrain cells, glutamate activated AP-1 (Condorelli et al., 1994), but not NF-кB (Lukasiuk et al., 1995), and, in nuclear extracts from whole brains of mice intracerebroventricularly injected with NMDA, no significant alterations were found in the binding activity of NF- $\kappa \mathrm{B}$, although an increase in the DNA-binding for AP-1 was observed (Yoneda and Ogita, 1994).

In this study, we observed that glutamate induces a greater increase of the DNA-binding activity of AP-1 than does kainate, and the increase was maximal $2 \mathrm{hr}$ after stimulation. In the absence of calcium, neither glutamate nor kainate was able to increase the AP-1 DNA-binding activity, which shows that the glutamate/kainate-induced 
increase in AP-1 DNA-binding activity is a receptormediated event. In cultured retinal neurons, the agonists of the ionotropic glutamate receptors increase the $\left[\mathrm{Ca}^{2+}\right]_{\mathrm{i}}$ through a composite effect, comprising $\mathrm{Ca}^{2+}$ permeating the receptor-associated channels and $\mathrm{Ca}^{2+}$ entering through voltage-gated $\mathrm{Ca}^{2+}$ channels activated upon cell depolarization after receptor activation (Duarte et al., 1996; Carvalho et al., 1998). Results from previous investigations of cultured neurons support the notion that $\mathrm{Ca}^{2+}$ plays a key role in the glutamate receptor agonist-induced activation of immediate early genes (IEG) and transcriptional activity (Lerea et al., 1992; Lerea an McNamara, 1993; Bading et al., 1993, 1995; Griffiths et al., 1998). The involvement of the ionotropic glutamate receptors in AP-1 DNA-binding activation has been demonstrated in other systems, such as rat cerebellar granule cells and striatal neurons (Hou et al., 1997; Schwarzschild et al., 1997; Kovács et al., 2000; Lidwell and Griffiths, 2000).

In previous work performed with cortical neurons, a sustained increase of the transcription factors that bind to the AP-1 consensus region was observed prior to the emergence of neuronal apoptotic-like cell death, suggesting that AP-1 binding factors could be involved in this process (Finiels et al., 1995). In cultured retinal neurons, the increase in the DNA-binding activity of AP-1 was observed early after the excitotoxic stimulation and precedes cell death, suggesting that activation of the AP-1 transcription factor could be involved in the retinal neuron death processes.

Different Fos/Jun heterodimers will have different transactivating potentials (Angel and Karin, 1991; Herdegen and Leah, 1998; Pennypacker, 1998). Consequently, different dimerization patterns of Fos and Jun proteins, induced by different stimuli, will cause functionally distinct effects on gene regulation. In this work, supershift experiments with several antibodies directed against different members of Fos and Jun protein families indicate that the AP-1 complex in retinal neurons includes proteins of the Fos family, namely, Fra-2, c-Jun, and Jun D. Additionally, Jun B and ATF 2 could also participate in the AP-1 complex. The pattern of AP-1 composition, after excitotoxic stimulation, was similar to that observed for control neurons. However, we cannot exclude the possibility that at least some other members of the Fos family participate in the AP-1 complex or that they might be differentially expressed relative to the control upon excitotoxic stimuli. A similar situation was previously described for cerebellar granule cells exposed to PDC, an inhibitor of glutamate reuptake; it was observed that PDC-induced AP-1 dimers, through the activation of NMDA receptors, which had the same composition as controls (Kovács et al., 1999).

\section{ERK Activation as a Cell-Intrinsic Neuroprotection Against Kainate Stimulation}

We demonstrate that, in primary cultures of chick embryo neuronal retina cells, there is an increase in ERK phosphorylation upon stimulation with glutamate or kai- nate. Neuronal ERKs can be activated in primary cultures of hippocampal neurons (Bading and Greenberg, 1991; Kurino et al., 1995), striatal neurons (Schwarzschild et al., 1999), and cortical neurons (Xia et al., 1996; Jiang et al., 2000) upon glutamatergic stimulation, through activation of the NMDA receptors, in a calcium-dependent manner. Although AMPA and kainate do not appear to activate ERK in hippocampal neurons (Kurino et al., 1995), for striatal neurons it was reported that both AMPA and kainate can activate ERK as a result of the direct influx of $\mathrm{Ca}^{2+}$ through the AMPA receptor itself (Perkinton et al., 1999).

In this study, we found that ERK activation by different glutamate agonists triggers a differential effect on cell viability of cultured retinal neurons. We observed that inhibition of MEK did not alter the toxicity induced by glutamate. However, when the toxic stimulation was performed with kainate, MEK inhibition induced a decrease in cell viability, suggesting that the ERK pathway could contribute to the survival of the retinal neurons when they are challenged with kainate. ERK was activated when retinal neurons were treated with kainate, and inhibition of ERK activation further increased kainate-induced cell death. These findings suggest that ERK does not actively contribute to the cell death caused by kainate but may be activated as a neuroprotective mechanism. Glutamate and kainate induce toxicity through the activation of different ionotropic glutamate receptors, so the observed differential effect of ERK activation on cell survival could be due to the different levels of toxicity mediated by NMDA and AMPA receptors or to the activation of different biochemical pathways by each receptor. A different localization of NMDA and AMPA receptors could also contribute to the different effect of ERK activation on cell survival upon excitotoxic stimulation. Other studies with neuronal cells have found that ERK activation functions as a cellintrinsic survival pathway (Hetman et al., 1999; Irving et al., 2000). For example, ERK is activated in cortical neurons treated with camptothecin (Hetman et al., 1999), and ERK pathway inhibition increases camptothecininduced apoptosis. In several cell lines, ERK is activated by $\mathrm{H}_{2} \mathrm{O}_{2}$ and low doses of radiation and provides protection against these stimuli (Guyton et al., 1996; Carter et al., 1998). However, evidence that ERK activation can be involved in a neurotoxic pathway has also been found (Murray et al., 1998; Jiang et al., 2000). Moreover, in other studies, MEK inhibition did not affect neuronal survival (Perkinton et al., 1999; Sugino et al., 2000).

The inhibitor of p38 did not change cell viability, suggesting that in retinal neurons this pathway is not involved in the excitotoxic response. In striatal neurons, glutamate failed to activate p38 (Scharzschild et al., 1997), but there are some reports with other neuronal systems implicating p38 in the toxic glutamatergic or ischemic response (Kawasaki et al., 1997; Irving et al., 2000; Sugino et al., 2000).

We propose that, in chick embryo retinal neurons, the excitotoxic responses induced by glutamate and kai- 
nate are mediated by different intracellular signaling cascades. We observed that stimulation of different ionotropic glutamate receptors induces different levels of toxicity. Furthermore, stimulation of retinal neurons with either glutamate or kainate causes an increase in ERK phosphorylation, although only kainate-induced ERK activation correlates with the activation of a survival signaling pathway. Probably glutamate-induced ERK activation subserves another functional role(s) in this system. In contrast, glutamate induces a greater increase in the AP-1 DNA-binding activity than kainate. Our results suggest that signaling pathways that mediate excitotoxic cell death and neuroprotection are stimulus specific in cultured chick amacrine-like cells.

\section{ACKNOWLEDGMENTS}

We are greatly indebted to Prof. Carlos B. Duarte for his advice and many helpful suggestions as well as for his critical revision of the manuscript. We thank Eli Lilly Co. for the gift of the 2,3-benzodiazepine LY303070.

\section{REFERENCES}

Ambrósio AF, Silva AP, Malva JO, Mesquita JF, Carvalho AP, Carvalho CM. 2000. Role of desensitisation of AMPA receptors on the neuronal viability and on $\left[\mathrm{Ca}^{2+}\right]_{\mathrm{i}}$ changes in cultured rat hippocampal neurons. Eur J Neurosci 12:2021-2031.

Angel P, Karin M. 1991. The role of Jun, Fos and the AP-1 complex in cell proliferation and transformation. Biochim Biophys Acta 1072:129-157.

Ankarcrona M, Dypbukt JM, Bonfoco E, Zhivotovsky B, Orrenius S, Lipton SA, Nicotera P. 1995. Glutamate-induced neuronal death: a succession of necrosis or apoptosis depending on mitochondrial function. Neuron 15:961-973.

Bading H, Greenberg ME. 1991. Stimulation of protein tyrosine phosphorylation by NMDA receptor activation. Science 253:912-914.

Bading H, Ginty DD, Greenberg ME. 1993. Regulation of gene expression in hippocampal neurons by distinct calcium signalling pathways. Science 260:181-186

Bading H, Segal MM, Sucher NJ, Dudek H, Lipton SA, Greenberg ME. 1995. N-methyl-D-aspartate receptors are critical for mediating the effects of glutamate on intracellular calcium concentration and immediate early gene expression in cultured hippocampal neurons. Neuroscience 64:653664.

Bettler B, Mulle C. 1995. Neurotransmitter receptors II: AMPA and kainate receptors. Neuropharmacology 34:123-139.

Bittigau P, Ikonomidou C. 1997. Glutamate in neurologic diseases. J Child Neurol 12:471-485.

Bonfoco E, Krainc D, Ankarcrona M, Nicotera P, Lipton SA. 1995. Apoptosis and necrosis: two distinct events induced, respectively, by mild and intense insults with $\mathrm{N}$-methyl-D-aspartate or nitric oxide/superoxide in cortical cell cultures. Proc Natl Acad Sci USA 92:7162-7166.

Carter S, Auer KL, Reardon DB, Birrer M, Fisher PB, Valerie K, SchmidtUllrich R, Mikkelsen R, Dent P. 1998. Inhibition of the mitogen activated protein (MAP) kinase cascade potentiates cell killing by low dose ionising radiation in A431 human squamous carcinoma cells. Oncogene 16:2787-2796.

Carvalho AL, Duarte CB, Faro CJ, Carvalho AP, Pires EV. 1998. Calcium influx through AMPA receptors and through calcium channels is regulated by protein kinase $\mathrm{C}$ in cultured retina amacrine-like cells. J Neurochem 70:2112-2119.

Cebers G, Liljequist S. 1995. Modulation of AMPA/Kainate receptors by cyclothiazides increases cytoplasmic free $\mathrm{Ca}^{2+}$ and ${ }^{45} \mathrm{Ca}^{2+}$ uptake in brain neurons. Eur J Pharmacol 290:105-115.
Cebers G, Zhivotovsky B, Ankarcrona M, Liljequist S. 1997. AMPA neurotoxicity in cultured cerebellar granule neurons: mode of cell death. Brian Res Bull 43:393-403.

Chen Q, Olney JW, Price MT, Romano C. 1999. Biochemical and morphological analysis of non-NMDA receptor mediated excitotoxicity in chick embryo retina. Vis Neurosci 16:131-139.

Choi DW. 1988. Calcium-mediated neurotoxicity: relationship to specific chnnel types and role in ischemic damage. Trends Neurosci 11:465-469.

Choi DW. 1996. Ischemia-induced neuronal apoptosis. Curr Opin Neurobiol 6:667-672.

Condorelli DF, Dell'Albani P, Amico C, Lukasiuk K, Kaczmarek L, Giuffrida-Stella AM. 1994. Glutamate receptor-driven activation of transcription factors in primary neuronal cultures. Neurochem Res 19:489499.

Doble A. 1999. The role of excitotoxicity in neurodegenerative disease: implications for therapy. Pharmacol Ther 81:163-221.

Donevan SD, Rogawski MA. 1993. GYKI 52466, a 2,3-benzodiazepine, is a highly selective, non-competitive antagonist of the AMPA/kainate receptor responses. Neuron 10:51-59.

Duarte CB, Ferreira IL, Santos PF, Oliveira CR, Carvalho AP. 1992. $\mathrm{Ca}^{2+}$-dependent release of $\left[{ }^{3} \mathrm{H}\right] \mathrm{GABA}$ in cultured chick retina cells. Brain Res 591:27-32.

Duarte CB, Santos PF, Carvalho AP. 1996. $\left[\mathrm{Ca}^{2+}\right]_{\mathrm{i}}$ Regulation by glutamate receptor agonists in cultured chick retina cells. Vis Res 36:10911102.

Duarte CB, Ferreira IL, Santos PF, Carvalho AL, Agostinho PM, Carvalho AP. 1998. Glutamate in life and death of retinal amacrine cells. Gen Pharmacol 30:289-295.

Encinas M, Iglesias M, Llecha N, Comella JX. 1999. Extracellular-regulated kinases and phosphatidylinositol 3-kinase are involved in brain-derived neurothrophic factor-mediated survival and neuritogenesis of the neuroblastoma cell line SH-SY5Y. J Neurochem 73:1409-1421.

Favata MF, Horiuchi KY, Manos EJ, Daulerio AJ, Stradley DA, Feeser WS, Van Dick DE, Pitts WJ, Earl RA, Hobbs F, Copeland RA, Magolda RL, Scherle PA, Trzaskos JM. 1998. Identification of a novel inhibitor of mitogen-activated protein kinase kinase. J Biol Chem 273:18623-18632.

Ferreira IL, Duarte CB, Carvalho AP. 1996. $\mathrm{Ca}^{2+}$ influx through glutamate receptor-associated channels in retina cells correlates with neuronal cell death. Eur J Pharmacol 302:153-162.

Ferreira IL, Duarte CB, Carvalho AP. 1998. Kainate-induced retina amacrine-like cell damage is mediated by AMPA receptors. Neuroreport 9:3471-3475.

Finiels F, Robert JJ, Samolyk ML, Privat A, Mallet J, Revah F. 1995. Induction of neuronal apoptosis by excitotoxins associated with long lasting increase of 12-O-tetradecanoylphorbol 13-acetate-responsive element-binding activity. J Neurochem 65:1027-1034.

Glazner GW, Chan SL, Lu C, Mattson MP. 2000. Caspase-mediated degradation of AMPA receptor subunits: a mechanism for preventing excitotoxic necrosis and ensuring apoptosis. J Neurosci 20:3641-3649.

Griffiths R, Ritchie L, Lidwell K, Grieve A, Malcolm CS, Scott M, Meredith C. 1998. Calcium-influx via L-type voltage gated channels mediates the delayed, elevated increases in steady-state $c$-fos mRNA levels in cerebellar granule cells exposed to excitotoxic levels of glutamate. J Neurosci Res 52:641-652.

Guyton KZ, Liu Y, Gorospe M, Xu Q, Holbrook NJ. 1996. Activation of mitogen-activated protein kinase by $\mathrm{H}_{2} \mathrm{O}_{2}$. Role in cell survival following oxidant injury. J Biol Chem 271:4138-4142.

Herdegen T, Leah JD. 1998. Inducible and constitutive transcription factors in the mammalian nervous system: control of gene expression by Jun, Fos and krox, and CREB/ATF proteins. Brain Res Rev 28:370-490.

Hetman M, Kanning K, Cavanaugh JE, Xia Z. 1999. Neuroprotection by brain-derived neurotrophic factor is mediated by extracellular signalregulated kinase and phosphatidylinositol 3-kinase. J Biol Chem 274: $22569-22580$. 
Hollmann M, Heinemann S. 1994. Cloned glutamate receptors. Annu Rev Neurosci 17:31-108.

Hou YN, Cebers G, Terenius L, Liljequist S. 1997. Characterization of NMDA- and AMPA-induced enhancement of AP-1 DNA binding activity in rat cerebellar granule cells. Brain Res 754:79-87.

Irving EA, Barone FC, Reith AD, Hadingham SJ, Parsons AA. 2000. Differential activation of MAPK/ERK and p38/SAPK in neurones and glia following focal cerebral ischemia in the rat. Mol Brain Res 77:65-75.

Itoh T, Itoh A, Horiuchi K, Pleasure D. 1998. AMPA receptor-mediated excitotoxicity in human NT2-N neurons results from loss of intracellular $\mathrm{Ca}^{2+}$ homeostasis following marked elevation of intracellular $\mathrm{Na}^{+}$. J Neurochem 71:112-124.

Jensen JB, Schousboe A, Pickering DS. 1998. AMPA receptor mediated excitotoxicity in neocortical neurons is developmentally regulated and dependent upon receptor desensitisation. Neurochem Int 32:505-513.

Jensen JB, Schousboe A, Pickering DS. 1999. Role of desensitisation and subunit expression for kainate receptor-mediated neurotoxicity in murine neocortical cultures. J Neurosci Res 55:208-217.

Jiang Q, Gu Z, Zhang G, Jing G. 2000. N-methyl-D-aspartate receptor activation results in regulation of extracellular signal-regulated kinases by protein kinases and phosphatases in glutamate-induced neuronal apoptotic-like death. Brain Res 887:285-292.

Kaminska B, Filipkowski RK, Zurkowska G, Lason W, Przewlocki R, Kaczmarek L. 1994. Dynamic changes in the composition of AP-1 transcription factor DNA-binding activity in rat brain following kainateinduced seizures and cell death. Eur J Neurosci 6:1558-1566.

Karin M. 1995. The regulation of AP-1 activity by mitogen-activated protein kinases. J Biol Chem 270:16483-16486.

Kasof GM, Mandelzys A, Maika SD, Hammer RE, Curran T, Morgan JI. 1995. Kainic acid-induced neuronal death is associated with DNA damage and a unique immediate-early gene response in $c$-fos-lac $Z$ transgenic rats. J Neurosci 15:4238-4249.

Katai N, Yoshimura N. 1999. Apoptotic retinal neuronal death by ischemia-reperfusion is executed by two distinct caspase family proteases. Invest Ophthalmol Vis Sci 40:2697-2705.

Kawasaki H, Morooka T, Shimohama S, Kimura J, Hirano T, Ggotoh Y, Nishida E. 1997. Activation and involvement of p38 mitogen-activated protein kinase in glutamate-induced apoptosis in rat cerebellar granule cells. J Biol Chem 272:18518-18521.

Kitayama T, Ogita K, Yoneda Y. 1999. Sustained potentiation of AP-1 DNA binding is not always associated with neuronal death following systemic administration of kainic acid in murine hippocampus. Neurochem Int 35:453-462.

Kovács AD, Cebers G, Liljequist S. 1999. Prolonged enhancement of AP-1 DNA binding by blockade of glutamate uptake in culture neurons. Neuroreport 10:1805-1809.

Kovács AD, Cebers G, Liljequist S. 2000. Kainate receptor-mediated activation of the AP-1 transcription factor complex in cultured rat cerebellar granule cells. Brain Res Bull 52:127-133.

Kurino M, Fukunaga K, Ushio Y, Miyamoto E. 1995. Activation of mitogen-activated protein kinase in rat hippocampal neurons by stimulation of glutamate receptors. J Neurochem 65:1282-1289.

Kwong JMK, Lam TT. 2000. N-methyl-D-aspartate (NMDA) induced apoptosis in adult rabbit retinas. Exp Eye Res 71:437-444.

Lam TT, Abler AS, Kwong JMK, Tso MOM. 1999. N-methyl-D-aspartate (NMDA)-induced apoptosis in rat retina. Invest Ophthalmol Vis Sci 40:2391-2397.

Lerea LS, McNamara JO. 1993. Ionotropic glutamate receptor subtypes activate $c$-fos transcription by distinct calcium-requiring intracellular signaling pathways. Neuron 10:31-41.

Lerea LS, Butler LS, McNamara JO. 1992. NMDA and non-NMDA receptor-mediated increase of $c$-fos mRNA in dentate gyrus neurons involves calcium influx via different routes. J Neurosci 12:2973-2981.

Lidwell K, Griffiths R. 2000. Possible role of Fos B/Jun D AP-1 transcrip- tion factor complex in glutamate-mediated excitotoxicity in cultured cerebellar granule cells. J Neurosci Res 62:427-439.

Lukasiuk K, Kaczmarek L, Condorelli DF. 1995. Inducible and constitutive transcription factor NF-kB-like DNA binding activities in rat brain cells cultured in vitro. Neurochem Int 26:173-178.

Martin LJ, Al-Abdulla NA, Brambrink AM, Kirsch JR, Sieber FE, PorteraCailliau C. 1998. Neurodegeneration in excitotoxicity, global cerebral ischemia, and target deprivation: a perspective on the contributions of apoptosis and necrosis. Brain Res Bull 46:281-309.

Mattson MP. 2000. Apoptosis in neurodegenerative disorders. Nature Rev Mol Cell Biol 1:120-129.

Mosmann T. 1983. Rapid colorimetric assay for cellular growth and survival: application to proliferation and cytotoxicity assays. J Immunol Methods 65:55-63.

Moudy AM, Yamada KA, Rothman SM. 1994. Rapid desensitisation determines the pharmacology of glutamate neurotoxicity. Neuropharmacology 33:953-962.

Murray B, Alessandrini A, Cole AJ, Yee AG, Furshpan EJ. 1998. Inhibition of the p44/42 MAP kinase pathway protects hippocampal neurons in a cell-culture model of seizure activity. Proc Natl Acad Sci USA 95:1197511980.

Ohno K, Okada M, Tsutsumi R, Kohara A, Yamaguchi T. 1997. Kainate excitotoxicity is mediated by AMPA- but not kainate-preferring receptors in embryonic rat hippocampal cultures. Neurochem Int 31:715-722.

Ohno K, Okada M, Tsutsumi R, Matsumoto N, Yamaguchi T. 1998. Characterisation of cyclothiazide-enhanced kainate excitotoxicity in rat hippocampal cultures. Neurochem Int 32:265-271.

Olney JW. 1978. Neurotoxicity of excitatory amino acids. In: McGeer E, Olney JW, McGeer P, editors. Kainic acid as a tool in neurobiology. New York: Raven Press. p 95-121.

Osborne NN, Herrera AJ. 1994. The effect of experimental ischaemia and excitatory amino acid agonists on the GABA and serotonin immunoreactivities on the rabbit retina. Neuroscience 59:1071-1081.

Osborne NN, Wood J, Muller A. 1995. The influence of experimental ischemia on protein kinase $\mathrm{C}$ and the GABAergic system in the rabbit retina. Neuropharmacology 34:1279-1288.

Osborne NN, Schwartz M, Pergande G. 1996. Protection of the rabbit retina from ischemia injury by flupirtine. Invest Ophthalmol Vis Sci 37:274-280.

Pateruain AV, Morales M, Lerma Y. 1995. Selective antagonism of AMPA receptors unmasks kainate receptor-mediated responses in hippocampal neurons. Neuron 14:185-189.

Patneau DK, Vyklicky L, Mayer ML. 1993. Hippocampal neurons exhibit cyclothiazide-sensitive rapidly desensitising responses to kainate. J Neurosci 13:3496-3509.

Pennypacker K. 1998. AP-1 transcription factors: short and long-term modulators of gene expression in the brain. Int Rev Neurobiol 42:169197.

Perez MTR, Arner K, Hakansson A. 1997. DNA fragmentation characteristic of apoptosis and cell loss induced by kainic acid in rabbit retinas. Neurochem Int 31:251-260.

Perkinton MS, Sihra TS, Williams RJ. 1999. $\mathrm{Ca}^{2+}$-permeable AMPA receptors induce phosphorylation of cAMP response element-binding protein through a phosphatidylinositol 3-kinase-dependent stimulation of the mitogen-activated protein kinase signaling cascade in neurons. J Neurosci 19:5861-5874.

Santos PS, Carvalho AL, Carvalho AP, Duarte CB. 1998. Differential acetylcholine and GABA release from cultured chick retina cells. Eur J Neurosci 10:2723-2730.

Schwarzschild MA, Cole RL, Hyman SE. 1997. Glutamate but not dopamine stimulates stress-activated protein kinase and AP-1 mediated transcription in striatal neurons. J Neurosci 17:3455-3466. 
Schwarzschild MA, Cole RL, Meyers MA, Hyman SE. 1999. Contrasting dependencies of SPAK and ERK activations by glutamate in cultured striatal neurons. J Neurochem 72:2248-2255.

Sugino T, Nozaki K, Takagi Y, Hattori I, Hashimoto N, Moriguchi T, Nishida E. 2000. Activation of the mitogen-activated protein kinases after transient forebrain ischemia in gerbil hippocampus. J Neurosci 20:45064514.

Tong L, Toliver-Kinsky T, Taglialatela G, Werrbach-Perez K, Wood T, Perez-Polo JR. 1998. Signal transduction in neuronal death. J Neurochem 71:447-459.

Wenzel A, Grimm C, Marti A, Kueng-Hitz N, Hafezi F, Niemeyer G, Remé CE. 2000. c-fos Controls the "private pathway" of light-induced apoptosis of retinal photoreceptors. J Neurosci 20:81-88.

White BC, Sullivan JM, DeGracia DJ, O’Neil BJ, Neumar RW, Grossman LI, Rafols JA, Krause GS. 2000. Brain ischemia and reperfusion: molecular mechanisms of neuronal injury. J Neurol Sci 179:1-33.
Xia Z, Dudek H, Miranti CK, Greenberg ME. 1996. Calcium influx via the NMDA receptor induces immediate early gene transcription by a MAP kinase/ERK-dependent mechanism. J Neurosci 16:54255436.

Yamada KA. 1998. Modulating excitatory synaptic neurotransmission: potential treatment for neurological disease? Neurobiol Dis 5:67-80.

Yoneda Y, Ogita K. 1994. Molecular biological studies on nuclear transcriptions factors expressed through the N-methyl-D-aspartate receptor complex. Jpn J Psychopharmacol 14:255-267.

Yoneda Y, Ogita K, Azuma Y, Kuramoto N, Manabe T, Kitayama T. 1999. Predominant expression of nuclear activator protein-1 complex with DNA binding activity following systemic administration of $\mathrm{N}$-methyl-D-aspartate in dentate granule cells of murine hippocampus. Neuroscience 93:19-31.

Zeevalk GD, Nicklas WJ. 1994. Nitric oxide in retina: relation to excitatory amino acids and excitotoxicity. Exp Eye Res 58:343-350. 